AT-TAJDID: Jurnal Pendidikan Dan Pemikiran Islam

(p-ISSN: 2548-5784 le-ISSN: 2549-2101)

Vol. (04)(01), (Januari-Juni) (2020), (Halaman)(1-20)

Doi: http://dx.doi.org/10.24127/att.v4i01.1163

\title{
PENINGKATAN HASIL BELAJAR SEJARAH KEBUDAYAAN ISLAM MELALUI MODEL COOPERATIVE LEARNING TIPE TEAM GAMES TOURNAMENT (TGT) DI MTS AL- QURANIYAH BENGKULU
}

\author{
Pasmah Chandra \\ IAIN Bengkulu \\ pasmah@iainbengkulu.ac.id
}

\begin{abstract}
ABSTRAK
Tujuan penelitian ini adalah untuk mengetahui apakah penerapan model pembelajaran kooperatif tipe Teams-Games-Tournament (TGT) dapat meningkatkan keaktifan proses pembelajaran di MTs Al-Quraniyah Bengkulu pada pokok bahasan khulafaurasyidin. Untuk mengetahui apakah penerapan model pembelajaran kooperatif tipe Teams-GamesTournament (TGT) dapat meningkatkan hasil belajar siswa kelas VII MTs Al-Quraniyah Bengkulu. Penelitian ini merupakan Penelitian Tindakan Kelas (PTK) dilakukan dalam tiga siklus, yang masing-maisng terdiri dari tahapan perencanaan, tindakan, pengamatan, dan refleksi. Proses pengumpulan data menggunakan observasi, wawancara, tes, dan dokumentasi. Data diolah dengan menggunakan analisis data kuantitatif. Hasil penelitian menunjukkan bahwa model pembelajaran kooperatif tipe TGT dapat meningkatak keaktifabnbelajar siswa pada mata pelajaran SKI di MTs Al-Quraniyah Bengkulu. Hal ini dapat terlihat dari hasil observasi terhadap tingkat keaktifan siswa dalam belajar, menunjukkan bahwa rata-rata yang diperoleh dari 9 aspek keaktifan belajar siswa pada siklus I sebesar $59,3 \%$ dan meningkat menjadi $67,55 \%$ pada siklus II dan meningkat kembali pada siklus III menjadi $80,3 \%$. Hasil belajar SKI siswa dapat ditingkatkan melalui model pembelajaran kooperatif tipet TGT. Hasil tes belajar siswa menunjukkan bahwa siswa yang mencapai KKM mengalami peningkatan dari $50 \%$ pada siklus I, kemudian meningkat menjadi $62,5 \%$ pada siklus II dan menjadi $100 \%$ pada siklus III.
\end{abstract}

Kata Kunci: Peningkatan, Hasil Belajar, Model Cooperative Learning Tipe TGT

\begin{abstract}
The purpose of this study was to determine whether the application of the Teams-GamesTournament (TGT) type of cooperative learning model could increase the activeness of the learning process in Al-Quraniyah Bengkulu MTs on the subject of khulafaurasyidin. To find out whether the application of the Teams-Games-Tournament (TGT) type of cooperative learning model can improve the learning outcomes of Grade VII students of Al-Quraniyah Bengkulu. This research is a Classroom Action Research (CAR) conducted in three cycles, each consisting of the stages of planning, action, observation, and reflection. The process of collecting data uses observation, interviews, tests, and documentation. Data is processed using quantitative data analysis. The results showed that the TGT type of cooperative learning model could increase student activity in SKI
\end{abstract}


subjects in Al-Quraniyah Bengkulu MTs. This can be seen from the results of observations on the level of student activity in learning, showing that the average obtained from 9 aspects of student learning activeness in cycle I was 59.3\% and increased to $67.55 \%$ in cycle II and increased again in the cycle III to $80.3 \%$. Student SKI learning outcomes can be improved through the TGT type of cooperative learning model. Student learning test results show that students who reach KKM have increased from 50\% in the first cycle, then increased to $62.5 \%$ in the second cycle and to $100 \%$ in the third cycle.

Keywords: Improvement, Learning Outcomes, TGT Type Cooperative Learning Model

\section{A. PENDAHULUAN}

Kemampuan seseorang
untuk memahami dan menyerap
pelajaran sudah pasti berbeda
tingkatnya. Ada yang cepat, sedang
dan ada pula yang sangat lambat. Karenanya, mereka seringkali harus menempuh cara berbeda untuk bisa memahami sebuah informasi atau pelajaran yang sama. Sebagian siswa lebih suka guru mereka mengajar dengan cara menuliskan segalanya di papan tulis. Dengan begitu mereka bisa membaca untuk kemudian mencoba memahaminya. Tapi, sebagian siswa lain lebih suka guru mereka mengajar dengan cara menyampaikannya secara lisan dan mereka mendengarkan untuk bisa memahaminya (Husna, 2018).

Sementara itu, ada siswa yang lebih suka membentuk kelompok kecil untuk mendiskusikan pertanyaan yang menyangkut pelajaran tersebut. Cara lain yang juga kerap disukai banyak siswa adalah model belajar yang menempatkan guru tak ubahnya seorang penceramah. Guru diharapkan bercerita panjang lebar tentang beragam teori dengan segudang ilustrasinya, sementara para siswa mendengarkan sambil menggambarkan isi ceramah itu dalam bentuk yang hanya mereka pahami sendiri.

Ada beberapa

permasalahan di Indonesia yang sampai saat ini belum terselesaikan secara tuntas. Antara lain: masalah pemerataan pendidikan, mutu pendidikan, efisiensi pendidikan dan masalah relevansi pendidikan. Memang kita perlu akui bahwa secara umum manusia Indonesia kurang dapat menggunakan kemampuan dan bakat yang dimilikinya (Suparda, 2012).

Hal ini kemungkinan dikarenakan kurang sadarnya masyarakat akan pentingnya ilmu pengetahuan dan betapa pentingnya mengoptimalkan sumber daya manusia untuk meningkatkan kesejahteraan kehidupan. Ada beberapa fenomena yang menarik bagi penulis untuk di teliti. Di dalam suatu komunitas pendidikan penulis melihat ada siswa yang lebih suka apabila pembelajaran dengan ditunjukkan gambar-gambar, ada siswa yang sangat senang belajar dengan ceramah yaitu mendengarkan guru, dan juga ada siswa yang senang belajar bergerak, dia tidak suka lama-lama duduk dibangku (Kholid, 2013). 
Selain permasalahan di atas, bagian penting yang harus diperhatiakan dalam dunia pendidikan ialah mengenai tenaga pendidik. Pendidik diharapkan dapat mengembangkan metode pembelajaran sesuai dengan standar kompetensi dan kompetensi dasar. Pencapaian seluruh kompetensi dasar perilaku terpuji dapat dilakukan tidak beraturan. Peran semua unsur sekolah, orang tua siswa dan masyarakat sangat penting dalam mendukung keberhasilan pencapaian tujuan Pendidikan Agama Islam (Sujarwo, 2015).

Suatu proses yang diinginkan dalam usaha pendidikan adalah proses yang terarah dan bertujuan yaitu mengarahkan anak didik kepada titik optimal kemampuannya. Sedangkan tujuan yang hendak dicapai adalah terbentuknya kepribadian yang bulat dan utuh sebagai manusia individual dan social serta hamba Tuhan yang mengabdikan diri kepada Nya.

Dalam pendidikan agama Islam, nilai-nilai yang hendak dibentuk adalah nilai-nilai Islam (Noormawanti, 2019). Artinya tujuan pembelajaran Pendidikan Agama Islam di Sekolah secara umum, yakni untuk meningkatkan keimanan, pemahaman, penghayatan, dan pengamalan peserta didik tentang Agama Islam, sehingga menjadi manusia muslim yang beriman dan bertakwa kepada Allah Swt serta berakhlak mulia dalam kehidupan pribadi, bermasyarakat, berbangsa dan bernegara. Adapun usaha pembelajaran Agama Islam di sekolah diharapkan agar mampu memebentuk kesalehan pribadi dan sekaligus kesalehan sosial (Muh Idris, 2013).

Mutu pendidikan dikatakan baik jika nilai hasil siswa menunjukkan peningkatan. Baik tidaknya hasil siswa ditentukan oleh beberapa faktor. Salah satu faktor yang paling dominan adalah guru. Dominasi guru dalam upaya peningkatan hasil siswa terjadi dalam proses pembelajaran di dalam kelas (Rosalina, 2012). Proses pembelajaran yang kurang menarik dan kurang variatif dapat menjadikan proses pembelajaran itu menjenuhkan. Akibatnya hasil siswa tidak dapat ditingkatkan. Sebaliknya hasil siswa dapat ditingkatkan jika ada upaya mengubah proses/ pembelajaran. Yakni dari proses pembelajaran yang menjenuhkan diubah menjadi proses pembelajaran yang menarik dan bahkan mungkin yang mengasikkan (Moh Saifullah, 2012).

Dalam proses belajar PAI tidak harus belajar dari guru kepada siswa, siswa juga bisa saling mengajar dengan sesama siswa yang lainnya. Strategi pembelajaran yang memberi kesempatan kepada siswa dalam tugas-tugas yang terstruktur disebut sebagai sistem "pembelajaran gotong royong" atau cooperatif learning, pola sistem ini guru bertindak sebagai fasilitator. Guru dalam melaksanakan proses 
belajar harus mampu memilih metode pengajaran yang relevan guna meningkatkan mutu pendidikan (Robert, 2015).

Banyak ahli berpendapat bahwa model pembelajaran kooperatif unggul dalam membantu siswa memahami konsep-konsep sulit. Model pembelajaran kooperatif mempunyai banyak sekali variasi. Salah satu di antaranya adalah model pembelajaran kooperatif tipe Teams Games Tournamens (TGT). Pembelajaran kooperatif model TGT adalah salah satu tipe atau model pembelajaran kooperatif yang mudah diterapkan, melibatkan aktivitas seluruh siswa tanpa harus ada perbedaan status, melibatkan peran siswa sebagai tutor sebaya dan mengandung unsur permainan dan reinforcement (Solihah, 2016). Aktivitas belajar dengan permainan yang dirancang dalam pembelajaran kooperatif model TGT memungkinkan siswa dapat belajar lebih rileks disamping menumbuhkan tanggung jawab, kerjsama, persaingan sehat dan keterlibatan belajar.

\section{B. METODE PENELITIAN}

Jenis penelitian yang dilakukan ialah Penelitian Tindakan Kelas (PTK) model Kemmis dan Mc Taggart. Konsep pokok PTK menurut Kemmis dan Mc Taggart terdiri dari empat komponen, yaitu: PTK mencakup empat langkah, yaitu: 1) perencanaan (planning), 2) tindakan (acting), 3) pengamatan (observing), 4) refleksi (reflecting). Keempat langkah tersebut bersifat spiral dan dipandang sebagai satu siklus. Penelitian ini menggunakan PTK dengan harapan guru SKI dapat memperbaiki kinerjanya sebagai guru dan menciptakan pembelajaran bermutu (Alecsandro, 2013).

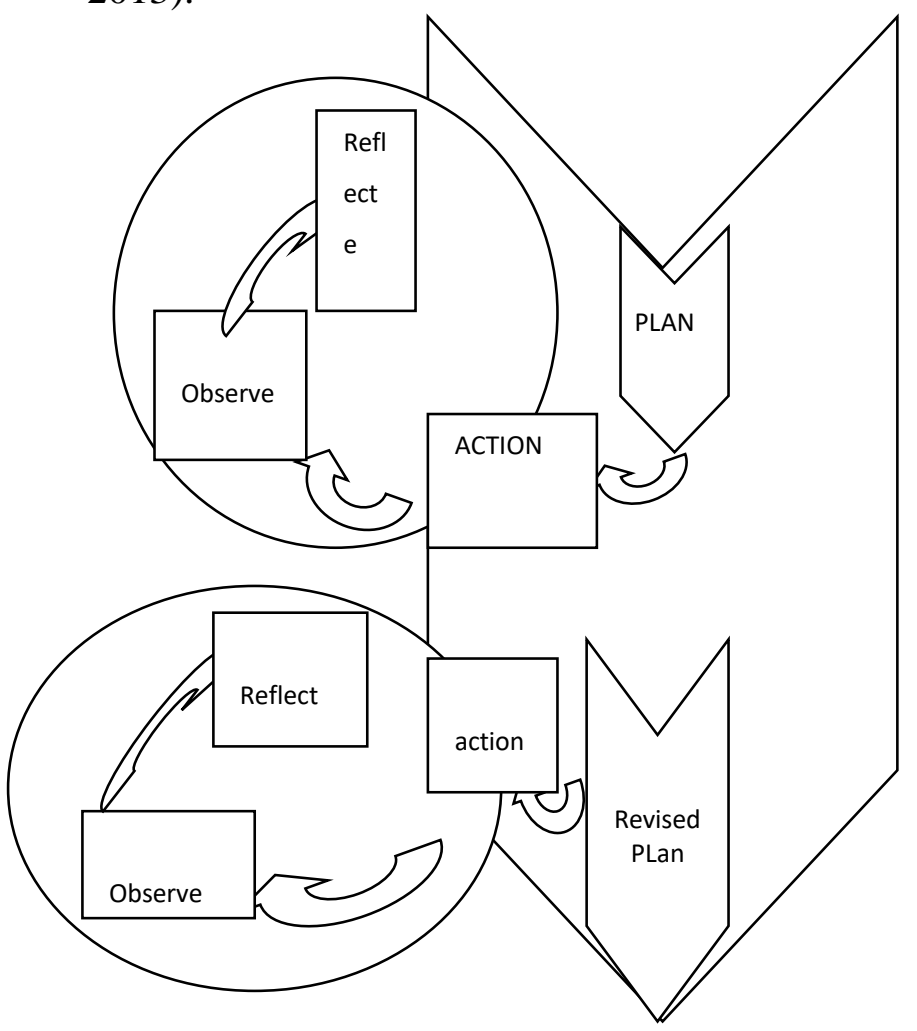

Siklus PTK menurut Kemmis dan Taggart (Siti, 2013).

Subjek penelitian ini adalah siswa kelas VII MTs Al-Quraniyah Bengkulu. Objek penelitian ini adalah pelaksanaan pembelajara SKI dengan model pembelajaran kooperatif tipe Teams Games Tournament (TGT).

Dalam penelitian digunakan setting kelas dan setting kelompok dimana data diperoleh pada saat proses belajar mengajar 
yang terjadi di dalam kelas dan kelompok.

Secara rinci prosedur penelitian tindakan kelas ini dapat dijabarkan sebagai berikut:

1. Siklus I

a. Perencanaan Tindakan

Kegiatan yang

perencanaan tindakan adalah menyusun rancangan yang akan dilaksanakan, sesuai dengan temuan masalah dan gagasan awal. Dalam perencanaan ini peneliti mengembangkan rencana pembelajaran, LKS, lembar observasi, dan pedoman wawancara di bawah bimbingan dosen. Pembuatan rencana pembelajaran dan LKS dikonsultasikan dengan pembimbing..

b. Pelaksanaan Tindakan

Pada tahap ini, guru melaksanakan desain pembelajaran kooperatif tipe TGT yang telah direncanakan. Dalam usaha kearah perbaikan suatu perencanaan bersifat fleksibel dan siap dilakukan perubahan sesuai apa yang terjadi dalam proses pelaksanaan di lapangan. Tahap pelaksanaan dalam pembelajaran kooperatif metode TGT ini meliputi:

1) Tahap mengajar

a) Guru memberikan kegiatan pembukaan b) Guru mengajarkan materi pelajaran secara garis besarnya saja

2) Tahap belajar dalam kelompok

a) Siswa berkelompok sesuai dengan kelompoknya masingmasing

b) Siswa mempunyai tugas untuk mempelajari materi pelajaran secara berkelompok dengan menggunakan LKS yang telah disiapkan

c) Wakil dari salah satu kelompok mempresentasikan hasil pengerjaan LKS

3) Tahap kompetisi

a) Setiap siswa mewakili kelompok masingmasing untuk bertanding dengan siswa yang mewakili kelompok lain dengan kemampuan setara

b) Nilai yang diperoleh siswa dikomulatifkan dengan teman sekelompoknya. Nilai rata-rata dari nilai komulatif tersebut menjadi nilai kelompok

4) Tahap Permainan

Permainan diikuti oleh semua kelompok. Permainan ini bertujuan untuk menjadikan pembelajaran SKI lebih menyenangkan. Permainan 
berisi

pertanyaan-

pertanyaan untuk menguji pengetahuan siswa yang diperoleh dari presentasai kelas dan belajar kelompok. Bentuk game dibuat oleh peneliti bersama dengan guru.

5) Tahap penghargaan

Penghargaan diberikan kepada:

a) Kelompok yang mempresentasikan hasil belajarnya.

b) Kelompok yang mempunyai nilai sesuai kriteria yang sudah ditentukan. Rata-rata poin dari hasil turnamen dan game digunakan sebagai penentu kriteria.

Berikut kriteria penentuan penghargaan:

Tabel 1. Kriteria penentuan penghargaan

\begin{tabular}{|l|l|}
\hline $\begin{array}{l}\text { Rata-rata } \\
\text { kelompok }\end{array}$ & $\begin{array}{l}\text { Penghargaan } \\
\text { kelompok }\end{array}$ \\
\hline $\begin{array}{l}45<\text { rata- } \\
\text { rata } \\
\text { kelompok } \\
<50\end{array}$ & $\begin{array}{l}\text { Good Team } \\
\text { (Tim Baik) }\end{array}$ \\
\hline $\begin{array}{l}50<\text { rata- } \\
\text { rata } \\
\text { kelompok } \\
<55\end{array}$ & $\begin{array}{l}\text { Great Team } \\
\text { (Tim Hebat) }\end{array}$ \\
\hline $\begin{array}{l}55<\text { rata- } \\
\text { rata } \\
\text { kelompok } \\
<60\end{array}$ & $\begin{array}{l}\text { Super Team } \\
\text { (Tim super) }\end{array}$ \\
\hline
\end{tabular}

c. Observasi

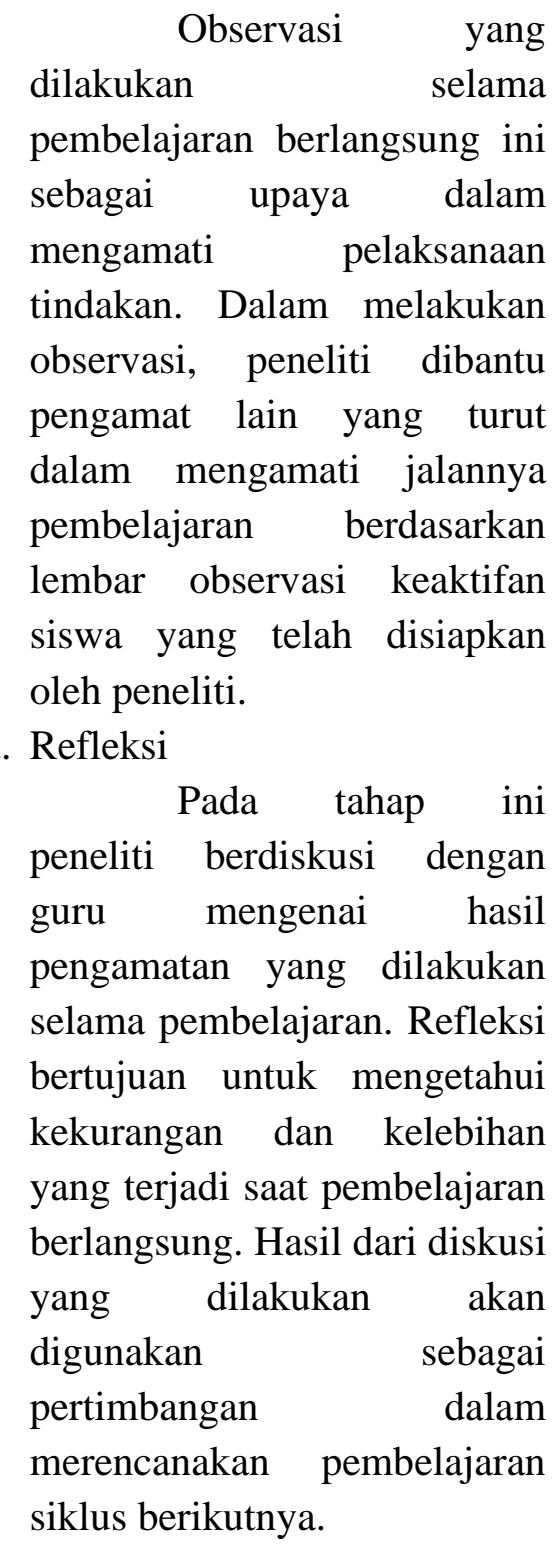

2. Siklus II

Kegiatan-kegiatan yang dilakukan pada siklus II dimaksudkan sebagai perbaikan terhadap pelaksanaan pembelajaran dengan TGT pada siklus I. Prosedur pelaksanaan pembelajaran pada siklus II sama dengan siklus I yaitu diawali dari perencanaan, pelaksanaan tindakan, observasi dan refleksi. Perencanaan tindakan pada siklus II dilakukan oleh peneliti dan 
guru dengan berdasarkan pada hasil refleksi pada siklus I. Apabila perubahan yang bertujuan meningkatkan kualitas pembelajaran telah tercapai, atau apa yang diteliti telah menunjukkan keberhasilan, siklus dapat diakhiri. Dan jika indikator belum tercapai, maka bisa dilanjutkan ke siklus berikutnya.

Untuk mendapatkan data, dipergunakan teknik pengumpulan data sebagai berikut yaitu:

a. Metode Observasi

Observasi merupakan indtrumen penelitianm utama yang digunakan oleh penelitian untuk memperoleh data keaktifan siswa selama proses pembelajaran berlangsung (Francisco). Observasi dilakukan oleh peneliti selama proses pembelajaran dengan menggunakan model pembelajaran kooperatif tipe TGT untuk mengetahui aktivitas siswa dalam pembelajaran tersebut. Observasi dilakukan dengan menggunakan lembar observasi keaktifa belajar siswa yang telah dipersiapkan. Adapun aspek-aspek yang akan diamati oleh penliti aialah kegiatan siswa dalam mencatat materi, mengajukan pendapat kepada guru atau teman, merespon pertanyaan daei guru atau siswa, berdiskusi atau berpastisipasi aktif dalam kelompok, mengerjakan LKS, mengerjakan soal turnamen, berpatisipasi dalam

permainan, mempersentasikan hasil kerja kelompok, serta memanfaatkan sumber belajar yang ada.

b. Metode Wawancara

$$
\text { Wawancara dalam }
$$

penelitian ini dilakukan terhadap guru dan siswa. Adapun guru yang akan diwawancarai ialah peneliti sendiri selaku guru SKI di MTs Al-Quraniyah Bengkulu. Proses wawancara terhadap guru akan dilakukan oleh observer yang merupakan guru mata pelajaran lain yang berada di sekolah tersebut. Adapaun siswa yang akan diwawancarai terdiri atas 2 siswa yang mewakili tiap kelompok. Wawancara digunakan untuk mengungkap data yang sulit dicari/ditemukan pada saat observasi. Wawancara yang dilakukan kepada siswa bertujuan untuk mengetahui perasaan siswa setelah dilakuakan proses pembelajaran SKI dengan metode TGT. Adapun materi yanga akan ditanyakan oleh peneliti ialah mengenai tanggapan-tanggapan siswa terhadap metode pembelajaran TGT yang dilakukan, perasaan mereka dengan diadakannya turnamen, dan lain-lain. Wawancara dilakukan secara terbuka dengan menggunakan pdedoman wawancara.

c. Dokumentasi

Dokumen yang digunakan berupa LKS, daftar 
kelompok siswa, daftar nilai siswa, foto kegiatan pembelajaran, dan rekaman. Dokumentasi dilakukan untuk memperkuat data yang diperoleh dari observasi. Dokumentasi foto dan rekaman untuk memberikan gambaran secara lebih nyata mengenai kegiatan kelompok siswa dan menggambarkan suasana kelas ketika aktivitas belajar berlangsung.

e. Tes

Pemberian tes dilakukan sebanyak dua kali, yaitu sebelum proses pembelajaran (pretes) dan setelah proses pembelajaran selesai (postes) pada tiap-tiap siklus (Suharsimi, 2006). Tes ini digunakan untuk mengukur ketuntasan atau hasil belajar siswa dalam menguasai materi yang telah diajarkan oleh guru melalui metode TGT. Tes diberikan kepada seluruh siswa, yaitu berjumlah 19 orang dengan bentuk soal berupa pilihan ganda (multiple choice).

Analisis data pada penelitian ini didasarkan pada refleksi tiap siklus tindakan. Hal ini bermanfaat untuk rencana perbaikan pembelajaran pada siklus berikutnya.

1. Analisis Data Hasil Observasi

Data hasil observasi aktivitas belajar siswa dianalisis dengan langkah-langkah sebagai berikut:

a. Berdasar pedoman penskoran yang telah dibuat, dihitung jumlah skor keseluruhan untuk kelas VII.

b. Skor keseluruhan untuk setiap observer dikomulatifkan kemudian dicari rataratanya.

d. Skor rata-rata tersebut dipersentase dan dikualifikasi dengan menggunakan kriteria sebagai berikut:

Table. 2 Kualifikasi Persentase Skor

\begin{tabular}{|c|c|}
\hline Rentang skor & kualifikasi \\
\hline $80-100 \%$ & Sangat tinggi \\
\hline $60-80 \%$ & Tinggi \\
\hline $40-60 \%$ & Sedang \\
\hline $20-40 \%$ & Rendah \\
\hline $0-20 \%$ & Sangat Rendah \\
\hline
\end{tabular}

2. Analisis Tes Hasil Belajar Siswa Setelah dilakukannya tes, baik sebelum meulai proses pembelajaran berupa pretes ataupun setelah prose pembelajaran berlangsung berupa postes maka peneliti akan mempersentasekan hasil belajar yang telah dicapai tersebut sehingga dapat mengukur apakah hasil belajar anak sudah tuntas atau belum atau setidaknya sudah mencapai kriteria ketuntasan minimal yang telah ditetapkan oleh guru yang bersangkutan. Penetuan ketuntasan berdasarkan penilaian acuan patokan, yaitu sejauh mana kemampuan yang ditargetkan dapat dikuasai siswa dengan cara menghitung proposri jumlah siswa yang menjawab 
benar dibagi dengan jumlah siswa seluruhnya. Rumusnya adalah:

$$
\mathrm{KB}=\frac{T}{T 1} X 100 \%
$$

Keterangan:

$\mathrm{KB}=$ ketuntasan belajar

$\mathrm{T}=$ jumlah skor yang diperoleh siswa

$\mathrm{T}_{1}=$ jumlah skor total (Rismurdiyati, 2013).

\section{HASIL DAN PEMBAHASAN}

Setelah dilakukan berbagai kegiatan mulai dari kegiatan pra penelitian sampai diberikan tindakan pasa siklus I, siklus II, dan siklus III maka diperoleh data dari hasil observasi, wawancara, dan tes hasil belajar SKI. Berikut ini adalah data hasil penelitian tindakan kelas pada siklus I, siklus II, dan siklus III. Berikut adalah data dan grafik hasil observasi:

Tabel 3

Data Hasil Observasi Keaktifan

\begin{tabular}{|c|c|c|c|c|}
\hline \multirow{2}{*}{ No } & \multirow{2}{*}{ Aspek yang diamati } & \multicolumn{3}{|c|}{ Hasil Observasi } \\
\hline & & Siklus I & Siklus II & Siklus III \\
\hline 1 & $\begin{array}{l}\text { Mencatat materi, ringkasan, dan } \\
\text { hasil pembahasan }\end{array}$ & $\begin{array}{c}56 \% \\
\text { (sedang) }\end{array}$ & $\begin{array}{c}62 \% \\
\text { (tinggi) }\end{array}$ & $\begin{array}{l}100 \% \\
\text { (sangat } \\
\text { tinggi) }\end{array}$ \\
\hline 2 & $\begin{array}{l}\text { Mengajukan pendapat kepada } \\
\text { guru atau teman/siswa lainnya }\end{array}$ & $\begin{array}{c}43 \% \\
\text { (sedang) }\end{array}$ & $\begin{array}{c}56 \% \\
\text { (sedang) }\end{array}$ & $\begin{array}{c}62 \% \\
\text { (tinggi) }\end{array}$ \\
\hline 3 & $\begin{array}{l}\text { Mersepon pernyataan atau respon } \\
\text { guru }\end{array}$ & $\begin{array}{c}62 \% \\
\text { (tinggi) }\end{array}$ & $\begin{array}{c}68 \% \\
\text { (tinggi) }\end{array}$ & $\begin{array}{c}68 \% \\
\text { (tinggi) }\end{array}$ \\
\hline 4 & $\begin{array}{l}\text { Beriskusi atau berpartisipasi } \\
\text { dalam kelompok }\end{array}$ & $\begin{array}{l}81 \% \\
\text { (sangat } \\
\text { tinggi) }\end{array}$ & $\begin{array}{l}87 \% \\
\text { (sangat } \\
\text { tinggi) }\end{array}$ & $\begin{array}{l}100 \% \\
\text { (sangat } \\
\text { tinggi) }\end{array}$ \\
\hline 5 & Mengerjakan LKS & $\begin{array}{c}68 \% \\
\text { (tinggi) }\end{array}$ & $\begin{array}{c}68 \% \\
\text { (tinggi) }\end{array}$ & $\begin{array}{c}68 \% \\
\text { (tinggi) }\end{array}$ \\
\hline 6 & $\begin{array}{l}\text { Memanfaatkan sumber belajar } \\
\text { yang ada }\end{array}$ & $\begin{array}{c}50 \% \\
\text { (sedang) }\end{array}$ & $\begin{array}{c}75 \% \\
\text { (tinggi) }\end{array}$ & $\begin{array}{l}100 \% \\
\text { (sangat } \\
\text { tinggi) }\end{array}$ \\
\hline 7 & $\begin{array}{l}\text { Mempersentasikan hasil kerja } \\
\text { kelompok }\end{array}$ & $\begin{array}{c}25 \% \\
\text { (rendah) }\end{array}$ & $\begin{array}{c}45 \% \\
\text { (sedang) }\end{array}$ & $\begin{array}{c}50 \% \\
\text { (sedang) }\end{array}$ \\
\hline 8 & $\begin{array}{l}\text { Berpartisipasi aktif dalam tahap } \\
\text { permainan }\end{array}$ & $\begin{array}{l}87 \% \\
\text { (sangat } \\
\text { tinggi) }\end{array}$ & $\begin{array}{l}87 \% \\
\text { (sangat } \\
\text { tinggi) }\end{array}$ & $\begin{array}{l}87 \% \\
\text { (sangat } \\
\text { tinggi) }\end{array}$ \\
\hline 9 & $\begin{array}{l}\text { Menghargai jawaban atau } \\
\text { pendapat orang lain }\end{array}$ & $\begin{array}{c}62 \% \\
\text { (tinggi) }\end{array}$ & $\begin{array}{c}62 \% \\
\text { (tinggi) }\end{array}$ & $\begin{array}{c}75 \% \\
\text { (tinggi) }\end{array}$ \\
\hline & Rata-rata keseluruhan & $\begin{array}{l}59,3 \% \\
\text { (sedang) }\end{array}$ & $\begin{array}{l}67,55 \% \\
\text { (tinggi) }\end{array}$ & $\begin{array}{l}80,3 \% \\
\text { (sangat } \\
\text { tinggi) }\end{array}$ \\
\hline
\end{tabular}

Sumber: Lembar observasi penelitian, 2019 


\section{Diagram 1.}

\section{Data Hasil Observasi Keaktifan Belajar SKI Siswa}

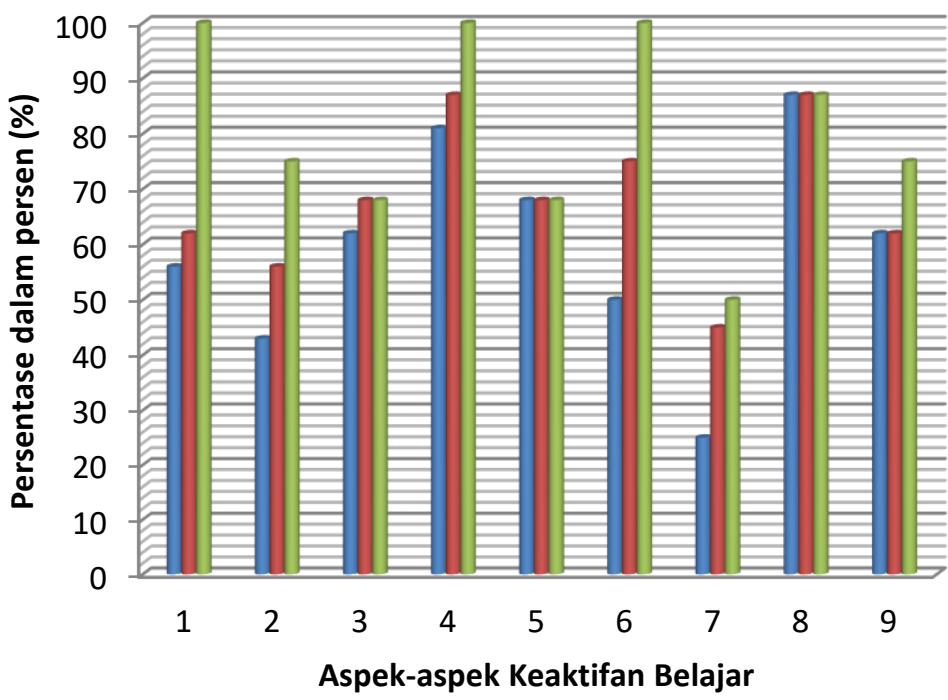

Siklus I

Siklus II

Siklus III

sumber observasi penelitian, 2019

Dari hasil pengolahan data di atas, dapat dipahami bahwa terdapat beberapa aspek keaktifan belajar siswa yang mengalami peningkatan cukup tinggi namun masih ada beberapa aspek yang hanya mengalami sedikit peningkatan. Pada aspek pertama, yaitu mencatat materi, ringkasan, dan hasil pembahasan mengalami peningkatan dari siklus I hanya 56 $\%$ kemudian meningkat sedikit menjadi $62 \%$ dan mengalami peningkatan yang signifikan hingga mencapai $100 \%$ atau maksimal.

Pada aspek kedua, yaitu mengajukan pendapat kepada guru atau teman/siswa lainnya mengalami peninngkatan pada tiap siklus. Pada siklus I hanya mencaapi $43 \%$ kmeudian berubah menjadi $56 \%$ kemudian meningkat lagi menjadi $75 \%$. Pada aspek ketiga, yaitu mersepon pernyataan atau respon guru juga mengalami peningkatan meskipun hanya sangat sedikit dan tidak mencapai angka $70 \%$. Aspek ketiga ini meningkat dari $62 \%$ kmeudian pada siklus II menjadi $68 \%$ dan tetap bertahan $68 \%$ pada siklus III.

Pada aspek keempat, yaitu berdiskusi atau berpartisipasi dalam kelompok mengalami peningkatan yang luar biasa, yaitu berawal dari siklu I yang sudah mencapai $81 \%$ kemudian naik menjadi $87 \%$ dan pada siklus III menjadi $100 \%$. Pada aspek kelima, yaitu mengerjakan lembar kerja siswa (LKS) tidak mengalami peningkatan, persentase yang diperoleh dari siklus I hingga siklus III hanya $68 \%$. Hanya ini tentunya dikarenakan hanya sebagian siswa saja atau ketua kelompok saja yang mengerjakan 
LKS sementara yang lain sibuk dengan perkerjaan lain yang terkadang membahasa hal-hal diluar pelajaran.

Pada aspek keenam, yaitu memanfaatkan sumber belajar yang ada, mengalami peningkatan yang bagus, yaitu berawal dari $50 \%$ pada siklus I kemudian meningkat menjadi $75 \%$ dan $100 \%$ pada siklus III. Pada pada aspek ketujuh, yaitu mempersentasikan hasil kerja kelompok hanya mengalami peningkatan sedikit sekali bahkan tidak mencapai $70 \%$. Peningkatan itu dimulai dari $25 \%$ menjadi $45 \%$ kemudian hanya meningkat menjadi 50\%.

Pada aspek kedelapan, yaitu berpartisipasi aktif dalam tahap permainan tidak mengalami peningkatan, hasilnya stagnan namun persentasenya sudah tinggi dari awal. Dari siklus I hingga siklus III hasilnya mencapai $87 \%$. Pada aspek kesembilan, yaitu menghargai jawaban atau pendapat orang lain mengalami peningkatan dari tiap siklus. Peningkaatn itu dari $62 \%$ pada siklus I dan II kemudian meningkat menjadi $75 \%$ pada siklus III.

Dari kesembilan aspek yang diobservasi, rata-rata dari total secara keseluruhan mengalami peningkatan. Peningkatan itu tampak pada siklus I 59,3\% kemudian naik menjadi $67,55 \%$ pada siklus II dan kembali meningkat pada siklus III menjadi 80,3\%. Dengan begitu hasil keaktifan belajar SKI pada siklus III sudah meningkat pada sebagian besar aspek dan secara persentase rata-rata sudah mengalami peningkatan pada aspek sangat tinggi. Jadi, dapat disimpulkan bahwa pembelajaran melalui model pembelajaran kooperatif tipe TGT sudah efektif dalam peningkatan keaktifan belajar SKI siswa.

Hasil evaluasi atau hasil belajar SKI yang diperoleh siswa pada siklus I, siklus II dan siklus III disajikan dalam tabel dan diagram berikut:

Tabel 4

Hasil Belajar SKI

\begin{tabular}{|c|c|c|c|c|c|c|}
\hline \multirow{2}{*}{$\begin{array}{c}\text { Respon } \\
\text { den }\end{array}$} & \multicolumn{2}{|c|}{ Siklus I } & \multicolumn{2}{c|}{ Siklus II } & \multicolumn{2}{c|}{ Siklus III } \\
\cline { 2 - 7 } & Skr & Nilai & Skr & Nilai & Skr & Nilai \\
\hline 1 & 10 & 50 & 11 & 55 & 14 & 70 \\
\hline 2 & 12 & 60 & 14 & 70 & 15 & 75 \\
\hline 3 & 14 & 70 & 12 & 60 & 14 & 70 \\
\hline 4 & 10 & 50 & 13 & 65 & 16 & 80 \\
\hline 5 & 11 & 55 & 16 & 80 & 18 & 90 \\
\hline 6 & 16 & 80 & 15 & 75 & 16 & 80 \\
\hline 7 & 14 & 70 & 15 & 75 & 18 & 90 \\
\hline 8 & 12 & 60 & 14 & 70 & 16 & 80 \\
\hline
\end{tabular}




\begin{tabular}{|c|c|c|c|c|c|c|}
\hline 9 & 13 & 65 & 12 & 60 & 15 & 75 \\
\hline 10 & 14 & 70 & 14 & 70 & 16 & 80 \\
\hline 11 & 12 & 60 & 15 & 75 & 16 & 80 \\
\hline 12 & 14 & 70 & 13 & 65 & 14 & 70 \\
\hline 13 & 16 & 80 & 16 & 80 & 20 & 100 \\
\hline 14 & 15 & 75 & 16 & 80 & 18 & 90 \\
\hline 15 & 12 & 60 & 14 & 70 & 15 & 75 \\
\hline 16 & 14 & 70 & 12 & 60 & 16 & 80 \\
\hline \multicolumn{2}{|c|}{ Jumlah } & 1035 & & 1110 & & 1285 \\
\cline { 1 - 2 } \cline { 6 - 7 } & & 65 & & 69 & & 80,3 \\
\hline
\end{tabular}

Sumber: Lembar penilaian tes siswa saat penelitian, 2019

\section{Diagram 2}

\section{Hasil Belajar SKI Siswa}

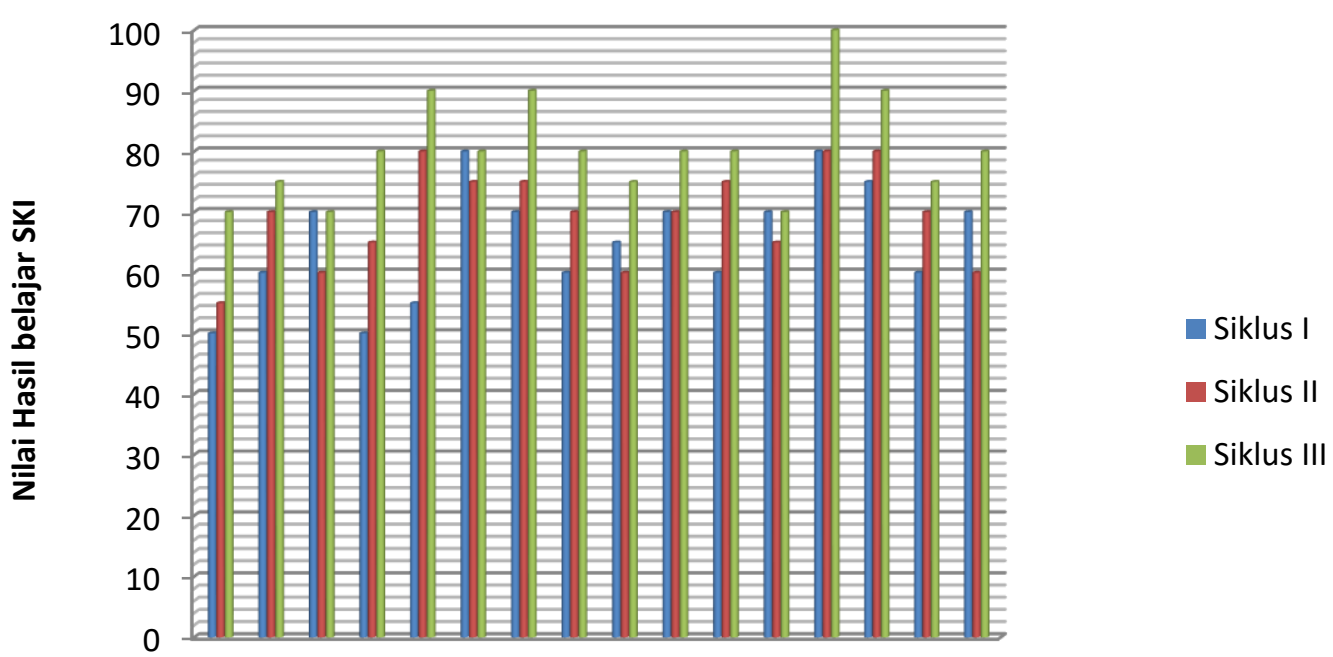

$\begin{array}{llllllllllllllll}1 & 2 & 3 & 4 & 5 & 6 & 7 & 8 & 9 & 10 & 11 & 12 & 13 & 14 & 15 & 16\end{array}$

Responden

Sumber: Lembar penialian tes siswa saat penelitian,2019.

Berdasarkan tabel dan grafik di atas, memperlihatkan bahwa penguasan siswa terhadap pelajaran SKI, khususnya bab khulafaurrasyidin sudah memuaskan. Nilai terendah pada siklus I, yaitu 50 sedangkan pada siklus III nilai terendah menjadi 70. Peningkatan jumlah siswa yang mendapat nilai minimal 70 dari 8 siswa pada siklus Imenjadi 16 siswa pada siklus III. Artinya pada siklus III seluruh siswa (100\%) telah mencapai nilai 70 atau mencapai KKM. Dari informasikan yang disampaikan menunjukkan terjadinya peningkatan hasil belajar SKI dari siklus I ke siklus II ke siklus III.

\section{Wawancara}

dilaksanakan 3 kali yaitu pada akhir pertemuan tiap siklus. 
Adapun hasil dari wawancara tersebut ialah:

a. Siswa merasa senang dan tertarik dengan pembelajaran kooperatif tipe TGT karena terdapat permainan (game).

b. Siswa lebih senang jika pelajaran SKI dilaksanakan dengan turnamen. Siswa menyatakan dengan adanya turnamen pembelajaran menjadi tidak membosankan. Justru sebaliknya pelajaran SKI menurut siswa menjadi lebih menarik dan menantang sehingga memacu mereka untuk belajar agar menang dalam turnamen.

c. Sebagian besar siswa mengakui bahwa mereka mengalami kesulitan saat ingin bertanya. Mereka merasa malu dan khawatir kalau yang ia tanyakan tidak berhubungan dengan pelajaran atau kualitas pertanyaan mereka tidak berbobot. Selain itu, siswa mengatakan bahwa mereka malu jika bertanya langusng dengan guru sehingga siswa lebih memilih bertanya dengan sesama teman.

d. Siswa juga merasa senang dengan adanya belajar kelompok dalam model pembelajran kooperatif tipe TGT karena apabila menemui kesulitan bisa bertanya pada teman sekelompoknya. Siswa mengatakan kalau waktu untuk belajar kelompok masih kurang sehingga terkadang siswa sedikit kesulitan dalam mengerjakan LKS.

e. Beberapa siswa merasa tidsk nyaman dalam kelompoknya karena masih ada anggota kelompoknya yang belum bisa diajak bekerjasama terutama dalam mengerjakan LKS. Siswa mengatakan, dalam mengerjakan LKS lebih banyak mengandalkan siswa yang cerdas yang berada di kelompok sementara yang lain hanya melihat saja.

f. Perhatian guru menurut siswa sudah menyeluruh. Guru selalu berkeliling baik dan menatap seluruh siswa baik pada presentasi maupun pada saat melaksanakan turnamen.

g. Siswa termotivasi untuk belajar agar kelompoknya menang dan mendapat hadiah (penghargaan).

Pembelajaran SKI dengan menggunakan model pembelajaran kooperatif tipe Teams Games Tournament (TGT) di MTs AlQuraniyah Bengkulu kelas VII telah dilakukan sesuai tahapan pelaksanaannya, yaitu presentasi kelas, belajar kelompok, turnamen, dan penghargaan kelompok. Indikator keberhasilan tindakan dalam penelitian ini adalah terjadinya peningkatan kekatifan dan hasil belajar SKI siswa. Hasil penelitian ini menunjukkan bahwa tingkat keaktifan siswa dalam belajar dan hasil belajar siswa dapat meningkat melalui model kooperatif teknik TGT. Hal ini dapat dilihat 
dari hasil observasi keaktifan siswa dan hasil tes belajar Ski siswa.

Dari hasil observasi terhadap tingkat keaktifan siswa dalam belajar, memperlihatkan bahwa rata-rata yang diperoleh dari 9 aspek keaktifan belajar siswa pada siklus I sebesar $59,3 \%$ dan meningkat menjadi $67,55 \%$ pada siklus II dan meningkat kembali pada siklus III menjadi 80,3\%. Siswa telah mengalami peningkatan pada sebagian besar aspek keaktifan yang diamati. Pada aspek mencatat materi, ringkasan, dan hasil pembahasan mengalami peningkatan dari siklus I hanya 56 $\%$ kemudian meningkat sedikit menjadi $62 \%$ dan mengalami peningkatan yang signifikan hingga mencapai $100 \%$ atau maksimal. Pada aspek mengajukan pendapat kepada guru atau teman/siswa lainnya mengalami peninngkatan pada tiap siklus. Pada siklus I hanya mencaapi $43 \%$ kmeudian berubah menjadi $56 \%$ kemudian meningkat lagi menjadi $75 \%$. Pada aspek ketiga, yaitu mersepon pernyataan atau respon guru juga mengalami peningkatan meskipun hanya sangat sedikit dan tidak mencapai angka $70 \%$. Aspek ketiga ini meningkat dari $62 \%$ kmeudian pada siklus II menjadi $68 \%$ dan tetap bertahan $68 \%$ pada siklus III.

Pada aspek berdiskusi atau berpartisipasi dalam kelompok mengalami peningkatan yang luar biasa, yaitu berawal dari siklu I yang sudah mencapai $81 \%$ kemudian naik menjadi $87 \%$ dan pada siklus III menjadi $100 \%$. Pada aspek kelima, yaitu mengerjakan lembar kerja siswa (LKS) tidak mengalami peningkatan, persentase yang diperoleh dari siklus I hingga siklus III hanya $68 \%$. Pada aspek memanfaatkan sumber belajar yang ada, mengalami peningkatan yang bagus, yaitu berawal dari 50\% pada siklus I kemudian meningkat menjadi $75 \%$ dan $100 \%$ pada siklus III. Pada pada aspek ketujuh, yaitu mempersentasikan hasil kerja kelompok hanya mengalami peningkatan sedikit sekali bahkan tidak mencapai $70 \%$. Peningkatan itu dimulai dari $25 \%$ menjadi $45 \%$ kemudian hanya meningkat menjadi $50 \%$.

Pada aspek berpartisipasi aktif dalam tahap permainan tidak mengalami peningkatan, hasilnya stagnan namun persentasenya sudah tinggi dari awal. Dari siklus I hingga siklus III hasilnya mencapai $87 \%$. Pada aspek kesembilan, yaitu menghargai jawaban atau pendapat orang lain mengalami peningkatan dari tiap siklus. Peningkaatn itu dari $62 \%$ pada siklus I dan II kemudian meningkat menjadi $75 \%$ pada siklus III. Pada aspek yang diobservasi, rata-rata dari total secara keseluruhan mengalami peningkatan. Peningkatan itu tampak pada siklus I $59,3 \%$ kemudian naik menjadi $67,55 \%$ pada siklus II dan kembali meningkat pada siklus III menjadi 80,3\%. Dengan begitu hasil keaktifan belajar SKI pada siklus III sudah meningkat pada sebagian 
besar aspek dan secara persentase rata-rata sudah mengalami peningkatan pada aspek sangat tinggi. Jadi, dapat disimpulkan bahwa pembelajaran melalui model pembelajaran kooperatif tipe TGT sudah efektif dalam peningkatan keaktifan belajar SKI siswa.

Pada hasil belajar SKI siswa pada siklus III dari aspek kognitif yaitu hasil belajar SKI yang diperoleh dari hasil tes dengan menggunakan tes pilihan ganda telah melampaui target. Seluruh siswa pada siklus III mendapat nilai di atas 70 atau telah melewati mencapai dan melewati. Peningkatan itu terjadi sangat tinggi, yaitu pada awalnya atau siklus I hanya 8 orang siswa yang mencapai KKM, kemudian pada siklus II meningkat menjadi 10 siswa dan pada siklus menjadi 16 orang (keseluruhan siswa)

Dari hasil wawancara dengan siswa, menunjukkan bahwa siswa senang dengan adanya model pembelajaran kooperatif tipe TGT dalam belajar SKI. Mereka tidak merasa bosan saat belajar. Justru mereka merasa pelajaran SKI yang awalnya tidak menarik dan membuat mengantuk menjadi pelajaran yang menarik dan menantang. Tentunya hal ini menurut siswa tidak terlepas dari adanya turnamen. Menurut siswa dengan adanya turnamen siswa berusaha untuk belajar lebih giat agar masing-masing dari mereka bisa memenangkan pertandingan dan membantu menambah poin bagi kelompoknya dalam meraih penghargaan. Dari wawancara, siswa juga mengatakan dengan adanya diskusi kelompok sebelum diadakannya turnamen membuat mereka bisa saling bertukar infomasi pelajaran dan saling bertanya satu sama lainnya.

Pada waktu tindakan, ternyata tidak hanya membantu siswa dalam memperoleh pengetahaun secara kogniif semata mengenai materi khulafaurrasyidin. Lebih dari itu, melalui model pembelajaran kooperatif tipe TGT ini dapat membangun sikap siswa, seperti saling bekerjasama yang baik dalam satu kelompok, saling tolongmenolong satu dan lainnya. Menimbulkan rasa tanggung jawab yang tinggi pada diri siswa karena setiap siswa harus belajar sehingga setiap perwakilan kelompok bisa memenangkan turnamen. Pada saat turnamen siswa diajarkan untuk sportif dalam bermain dan menghargai pendapat orang meskipun kita tidak sependapat dengan diirnya.

Pembelajaran deengan teknik TGT ini lebih banyak memberikan kesempatan kepada siswa untuk aktif sehingga guru lebih berfungsi sebagai fasilitator pembelajaran dan motivator bagi siswa dalam mengembangkan pengetahuan, keterampilan, dan sikap-sikapnya (Rian, 2013). Melalui model pembelajaran kooperatif tipe TGT secara keseluruhan terbukti sangat efektif dalam meningkatan keaktifan 
belajar dan hasil belajar. Hal ini tentunya tidak terlepas dari substansi bidang SKI itu sendiri. Untuk mencapai tujuan pembelajaran SKI secara utuh tidak cukup hanya dengan mentrasnfer pengetahuan kepada peserta didik tetapi juga bagaimana agar nilainilai sejarah yang ada dalam pelajaran dapat dipahami oleh siswa sehingga dapat dijadikan sebagai contoh dan panutan dalam kehidupan sehari-hari. Tentunya untuk dapat melakukan itu semua pelajaran SKI harus dibuat semenarik mungkin.

Model pembelajaran kooperatif tipe TGT merupakan salah satu dari model pembelajaran yang mengarah pada pengembangan keterampilan siswa dalam memperoleh pengetahuan (Tara, 2019). Pembelajaran melalui model ini lebih bermakna karena kegiatan ini menempatkan aktifitas siswa sebagai yang utama dengan lebih banyak memberikan kesempatan kepada siswa secara leluasa dalam memperoelh ilmu pengetahuan, misal melalui diskusi, presentasi kelompok, dan turnamen.

Berdasarkan uraian yang telah dikemukakan di atas, dapat dinyatakan bahwa:

1. Melalui model pembelajaran kooperatif tipe TGT sangat efektif dalam meningkatkan keaktifan dalam proses pembelajaran SKI sehingga mampu memperoleh hasil belajar SKI siswa yang tinggi pula.
2. Setelah peneliti melakukan penelitian, maka menurut peneliti model pembelejaran kooperatif tipe TGT ini memiliki kelebihan dan kekurangan, diantaranya:

\section{Kelebihan TGT:}

a. Siswa lebih termotivasi untuk belajar jika dibandingkan dengan pola pembalajaran konvensional sehingga dapat memberikan dan menciptakan suasana belajar yang menarik dan menyenangkan.

b. Meningkatkan interaksi antar siswa secara aktif dan melibatkan segenap kemampuan yang dimiliki siswa, begitu juga dengan interaksi antara siswa dan guru sehingga menimbulkan feed back terhadap materi yang diajarkan.

c. Meningkatkan prestasi atau hasil belajar siswa (secara kognitif), khususnya mata pelajaran yang diteliti yaitu SKI.

d. Menimbulkan kecerdasan sosial atau nilai afektif pada siswa, seperti rasa tanggung jawab siswa untuk berbuat terbaik bagi kelompoknya, kerjasa sama yang baik dalam satu kelompok, menghargai pendapat orang lain (toleransi), percaya terhadap kemampuan yang ada, mengedepankan penerimaan terhadap perbedaan individu.

Kelemahan TGT:

a. Bagi guru 
1) Kurang efisien terhadap waktu yang ada karena membutuhkan waktu yang lama dalam persiapan turnamennya. Kelemahan di atasi jika peneliti menyiapkan perencanaan untuk permainan jauh-jauh hari atau setidaknya sudah perencanaan pada pembuatan RPP awal tahun ajaran. Selain itu, untuk mempermudah dalam turnamen, guru bisa berkolaborasi dengan sesama guru pada bidang mata pelajaran terssebut dalam satu sekolah.

2) Sulitnya mengelompokkan siswa yang mempunyai kemampuan heterogen dari segi akademis. Kelemahan ini akan dapat diatasi jika guru yang bertindak sebagai pemegang kendali, teliti dalam menentukan pembagian kelompok.

3) Waktu yang dihabiskan untuk diskusi oleh siswa cukup banyak, sehingga terkadang melewati waktu yang sudah ditetapkan. Kesulitan ini dapat diatasi jika guru mampu menguasai kelas secara menyeluruh.

b. Bagi siswa

Masih adanya siswa berkemampuan tinggi kurang trebiasa dan sulit memberikan penjelasan kepada siswa lainnya. Untuk mengatasi kelemahan ini, tugas guru adalah membimbing dengan baik siswa yang mempunyai kemampuan akademik tinggi agar dapat dan mampu menularkan pengetahuannya kepada siswa yang lain.

3. Untuk melakukan penelitian ke tahap lebih lanjut atau pengembangan metode TGT ini dalam proses pembelajaran, maka menurut peneliti haru memenuhi beberapa ketentuan atau syarat sehingga hasilnya bisa optimal. Adapun ketensuan tersebut, diantaranya:

a. Harus ada usaha yang lebih dari guru terutama menyangkut dana dan waktu mempersiapkan pembelajarannya

b. Guru yang menerapkan metode pembelajaran ini harus memiliki komitmen yang tinggi dan wawasan yang cukup. Berbagai masalah yang mungkin dihadapi oleh guru di masamasa awal pembelajaran akan dapat diatasi dengan sendirinya jika guru memiliki komitmen, semangat, dan wawasan yang cukup.

c. Penerapan pembelajaran melalui model pembelajaran kooperatif tipe TGT agak terasa sulit jika dilakukan, terutama oleh pemula, maka guru bisa meminta bantuan pada guru sejawat pada mata 
pelajaran yang sama di sekolah tersebut.

4. Pelaksanaan turnamen dalam model pembelajaran kooperatif tipe TGT ini tidak harus dilaksanakan di dalam kelas, namun pelaksanaannya bisa di lingkungan sekolah. Peneliti pernah melakukan percobaan sebagai lanjutan dari TGT yang telah dilaksanakan dan ternyata hasil membuat anak lebih rileks dalam melakukan turnamen. Selain itu, cara pengambilan nomor untuk menentukan pembaca soal bisa dilakukan modifikasi dengan melempar bola dadu yang telah dimodif (dibuat sendiri). Namun tentunya hal ini memerlukan penelitian lebih lanjut.

\section{KESIMPULAN}

Berdasarkan hasil analisis data dan pembahasan, dapat diambil beberapa kesimpualn sebagai berikut:

1. Model pembelajaran kooperatif tipe TGT dapat meningkatak keaktifab belajar siswa pada mata pelajaran SKI di MTs AlQuraniyah Bengkulu. Hal ini dapat terlihat dari hasil observasi terhadap tingkat keaktifan siswa dalam belajar, menunjukkan bahwa rata-rata yang diperoleh dari 9 aspek keaktifan belajar siswa pada siklus I sebesar $59,3 \%$ dan meningkat menjadi $67,55 \%$ pada siklus II dan meningkat kembali pada siklus III menjadi $80,3 \%$.

2. Hasil belajar SKI siswa dapat ditingkatkan melalui model pembelajaran kooperatif tipet TGT. Hasil tes belajar siswa menunjukkan bahwa siswa yang mencapai KKM mengalami peningkatan dari $50 \%$ pada siklus I, kemudian meningkat menjadi $62,5 \%$ pada siklus II dan menjadi $100 \%$ pada siklus III.

3. Penerapan model pembelajaran kooperatif tipet TGT di MTs Al-Quraniyah Bengkulu membuat pelajaran SKI menajdi menyenangkan dan menarik bagi siswa.

\section{E. DAFTAR PUSTAKA}

\section{Buku}

Arikunto, Suharsimi, (2006). Prosedur Penelitian Tindakan Kelas, Jakarta: Bumi Aksara.

Ariyanto, Rian Rifqi, \& Miftahul Huda, (2013). Model-Model

Pengajaran Dan

Pembelajaran: Isu-Isu

Metodis Dan Paradigmatis.

Yogyakarta: Pustaka

Pelajar.

Dinni, Husna Nur, (2018). HOTS

( High Order Thinking Skills

) Dan Kaitannya Dengan

Kemampuan Literasi

Matematika, Prisma.

\section{Jurnal}

Ai, Solihah, (2016). "Pengaruh 
Model Pembelajaran Team

Games Tounamaent (TGT)

Terhadap Hasil Belajar

Matematika". Jurnal SAP

Vol.

Francisco, Alecsandro Roberto

Lemos.

(2013)

"PENELITIAN TINDAKAN

KELAS (PTK)". Journal of

Chemical Information and

Modeling.

Ginting, Rosalina, and Titik

Haryati, (2012).

"Kepemimpinan Dan

Konteks Peningkatan Mutu

Pendidikan". Jurnal Ilmiah CIVIS.

Idris, Muh, (2013). "Reformasi

Pendidikan Islam Di

Indonesia". Marwah: Jurnal

Perempuan, Agama Dan

Jender.

<https://doi.org/10.24014/ma

rwah.v12i1.512>

Khasinah, Siti, (2013).

"Classroom Action

Research". Jurnal Pionir,

Volume 1, Nomor 1.

<https://doi.org/10.17977/um

013v1i42017p156>

Musyaddad, Kholid, (2013).

"Problematika Pendidikan Di

Indonesia", Edu-Bio.

Noormawanti,

(2019).

"Implementasi Pembelajaran

Pendidikan Agama Islam Di

Sekolah Dasar (SD)

Muhammadiyah Metro

Pusat". At-Tajdid: Jurnal

Pendidikan Dan Pemikiran

Islam, 2.01.

Rismurdiyati, (2013). "Upaya
Meningkatkan Hasil Belajar Ipa Menggunakan Media Pembelajaran Berupa Charta Untuk Materi Sistem Pencernaan Pada Manusia". Jurnal Formatif 2(3): 235247 ISSN: 2088-351X, $<$ https://doi.org/10.4172/232 9-6925.1000259>

Saifulloh, Moh, Zainul Muhibbin, \& Hermanto Hermanto, (2012). "Strategi Peningkatan Mutu Pendidikan Di Sekolah" Jurnal Sosial Humanior. <https://doi.org/10.12962/j24 433527.v5i2.619>

Slavin, Robert E, (2015). "Cooperative Learning in Elementary Schools". Education 3-13. $<$ https://doi.org/10.1080/030 04279.2015.963370>

Sujarwo, (2015) "Pendidikan Di Indonesia Memprihatinkan". Jurnal Ilmiah WUNY.<https://doi.org/10.2 1831/jwuny.v15i1.3528>

Supardi, (2012). "Arah Pendidikan Di Indonesia', Arah Pendidikan Di Indonesia Dalam Tataran Kebijakan Dan Implementasi".

Ulfia, Tara, and Irwandani Irwandani, (2019). "Model Pembelajaran Kooperative Tipe Teams Games Tournament (TGT): Pengaruhnya Terhadap Pemahaman Konsep". Indonesian Journal of 
Science and Mathematics

Education.

<https://doi.org/10.24042/ijs

me.v2i1.4220>

Copyright @ 2020, Universitas Muhammadiyah Metro| 20 